Article

\title{
A Novel Strategy for Creating an Antibacterial Surface Using a Highly Efficient Electrospray-Based Method for Silica Deposition
}

\author{
Odelia Levana ${ }^{1,2,+}$, Soonkook Hong ${ }^{3,+}$, Se Hyun Kim ${ }^{4}$, Ji Hoon Jeong ${ }^{1,2}$, Sung Sik Hur ${ }^{1}$, Jin Woo Lee ${ }^{5}$, \\ Kye-Si Kwon 4,6,*(D) and Yongsung Hwang 1,2,*(D)
}

1 Soonchunhyang Institute of Medi-Bio Science (SIMS), Soonchunhyang University, Cheonan-si 31151, Chungnam-do, Korea; odelialevana@sch.ac.kr (O.L.); jjh2020@sch.ac.kr (J.H.J.); sstahur@sch.ac.kr (S.S.H.)

2 Department of Integrated Biomedical Science, Soonchunhyang University, Asan-si 31538, Chungnam-do, Korea

3 Department of Mechanical and Naval Architectural Engineering, Republic of Korea Naval Academy, Changwon-si 51704, Kyungsangnam-do, Korea; hsk753@mnd.go.kr

4 Department of Electronic Materials, Devices and Equipment Engineering, Soonchunhyang University, Asan-si 31538, Chungnam-do, Korea; ksy9046@naver.com

5 Department of Molecular Medicine, Gachon University College of Medicine, Incheon 21936, Korea; jwlee@gachon.ac.kr

6 Department of Mechanical Engineering, Soonchunhyang University, Asan-si 31538, Chungnam-do, Korea

* Correspondence: kskwon@sch.ac.kr (K.-S.K.); yshwang0428@sch.ac.kr (Y.H.); Tel.: +82-41-530-1670 (K.-S.K.); +82-41-413-5017 (Y.H.)

+ These authors contributed equally to this study.

\section{check for}

updates

Citation: Levana, O.; Hong, S.; Kim, S.H.; Jeong, J.H.; Hur, S.S.; Lee, J.W.; Kwon, K.-S.; Hwang, Y. A Novel Strategy for Creating an Antibacterial Surface Using a Highly Efficient Electrospray-Based Method for Silica Deposition. Int. J. Mol. Sci. 2022, 23, 513. https://doi.org/10.3390/ ijms23010513

Academic Editor: Ana

María Díez-Pascual

Received: 8 December 2021

Accepted: 31 December 2021

Published: 3 January 2022

Publisher's Note: MDPI stays neutral with regard to jurisdictional claims in published maps and institutional affiliations.

Copyright: (C) 2022 by the authors. Licensee MDPI, Basel, Switzerland. This article is an open access article distributed under the terms and conditions of the Creative Commons Attribution (CC BY) license (https:// creativecommons.org/licenses/by/ $4.0 /)$.

\begin{abstract}
Adhesion of bacteria on biomedical implant surfaces is a prerequisite for biofilm formation, which may increase the chances of infection and chronic inflammation. In this study, we employed a novel electrospray-based technique to develop an antibacterial surface by efficiently depositing silica homogeneously onto polyethylene terephthalate (PET) film to achieve hydrophobic and antiadhesive properties. We evaluated its potential application in inhibiting bacterial adhesion using both Gram-negative Escherichia coli (E. coli) and Gram-positive Staphylococcus aureus (S. aureus) bacteria. These silica-deposited PET surfaces could provide hydrophobic surfaces with a water contact angle greater than $120^{\circ}$ as well as increased surface roughness (root mean square roughness value of $82.50 \pm 16.22 \mathrm{~nm}$ and average roughness value of $65.15 \pm 15.26 \mathrm{~nm}$ ) that could significantly reduce bacterial adhesion by approximately $66.30 \%$ and $64.09 \%$ for E. coli and S. aureus, respectively, compared with those on plain PET surfaces. Furthermore, we observed that silica-deposited PET surfaces showed no detrimental effects on cell viability in human dermal fibroblasts, as confirmed by MTT (3-(4,5-dimethylthiazol-2-yl)-2,5 diphenyl tetrazolium bromide and live/dead assays. Taken together, such approaches that are easy to synthesize, cost effective, and efficient, and could provide innovative strategies for preventing bacterial adhesion on biomedical implant surfaces in the clinical setting.
\end{abstract}

Keywords: electrospray; antibacterial surface; hydrophobicity; silica deposition; anti-adhesive properties

\section{Introduction}

Biofilms are sessile bacterial aggregates that firmly adhere to both living and nonliving surfaces [1]. Bacterial adhesion is modulated by physical forces, including non-specific van der Waals, Lewis acid-base, and electrostatic forces, or bacterial appendages, such as pili or flagella $[2,3]$. Newly formed biofilms at the interfaces of a material surface or living body produce an exopolysaccharide (EPS) matrix, which accelerates the continuous growth, maturation, and propagation from the original region to other locations by strengthening cell-cell, cell-tissue, and cell-surface interactions as well as increases stress 
resistance against harsh conditions, such as heat and acidic shock [4]. Moreover, the EPS matrix consists of polymeric substances that can retard antibiotic penetration, which eventually increases antimicrobial resistance and causes difficulties in clinical treatment $[5,6]$. Therefore, a preventive strategy is required to inhibit initial bacterial attachment and their continuous growth.

Bactericidal agents, such as antibiotics and biocides, can be effectively applied on biocidal surfaces; however, the accumulation of dead bacteria and other debris on the surface could lead to the initiation of acute inflammation $[7,8]$. To overcome this drawback, the incorporation of metal chelators, such as ethylenediaminetetraacetic acid and citrate, onto the surface has been reported to disrupt bacterial surface adherence without killing the cells directly $[9,10]$. Another study by Asadi et al. [11] demonstrated the development of sugar-based host receptor analogs with the potential to weaken bacterial adhesion to the surface. Among these approaches, the fabrication of hydrophobic surfaces with antiadhesive properties has been extensively studied, particularly in the healthcare industry, because bacterial infections are often caused by medical equipment [12].

Bacterial adhesion on the surface is mediated by surface wettability, and various methods, such as lithography, etching, templating, sol-gel method, layer-by-layer deposition, and spray coating, have been used to generate hydrophobic surfaces [13-15]. Among these techniques, electrospray has been widely used to create hydrophobic surfaces with antibacterial properties [16]. Nanoparticles are commonly utilized for electrospray-based coatings; for example, titania $\left(\mathrm{TiO}_{2}\right)$ effectively inhibits Escherichia coli (E. coli) and Staphylococcus aureus (S. aureus) adhesion on surfaces owing to the hydrophobic properties of the nanoparticles, as reported in previous studies [16,17]. Moreover, silica $\left(\mathrm{SiO}_{2}\right)$ shows good biocompatibility and has been developed as coating materials, particularly in biomedical applications, such as urinary catheters and dental implants [18-20].

Polyethylene terephthalate (PET) has been widely used in the healthcare industry due to its mechanical properties, such as high biocompatibility and uniformity, as well as high mechanical strength [21]. However, bacterial contamination on PET surface is one of the drawbacks and has been commonly reported from its application in medical devices [22]. Therefore, in this study, we aimed to develop a novel electrospray technique to create a hydrophobic silica-rich surface with anti-adhesive properties and evaluate its potential as an antibacterial surface to inhibit initial bacterial adhesion. PET substrate was deposited with silica using a highly efficient electrospray-based method, and sample characterization was performed using scanning electron microscopy (SEM), Fourier-transform infrared spectroscopy (FTIR), and atomic force microscopy (AFM), whereas hydrophobicity was analyzed by water contact angle (WCA) measurements. The antibacterial properties of the fabricated surface were investigated using E. coli and S. aureus as Gram-negative and Gram-positive model bacteria, respectively. Our method effectively inhibited bacterial adhesion on the surface without any cytotoxic effects on human dermal fibroblasts, as assessed by cytotoxicity tests. Therefore, our findings could be applied in biomedical applications as an alternative method of antibiotic usage.

\section{Results}

\subsection{Fabrication of a $\mathrm{SiO}_{2}$-Deposited Surface Using an Electrospray Technique}

In this study, we focused on the fabrication of silica-deposited PET using the novel alternating current (AC)-biased method for efficiently creating homogenous hydrophobic surfaces, as displayed in Figure 1. Silica $\left(\mathrm{SiO}_{2}\right)$ solution was prepared as the material for electrospray coating and loaded into a nozzle. A low air pressure with $2.0 \mathrm{kPa}$ and high DC voltage $(5 \mathrm{kV})$ was applied to the syringe barrel in order to prevent the dripping of large droplets from the nozzle, resulting in sprayed charge droplets that were easily attached to PET surfaces. In contrast to the conventional electrospray method, we applied AC voltage under the substrate holder as a replacement of ground (zero) voltage to improve the uniformity of electrospray-based silica deposition and reduce the effect of undissipated charges. 
A

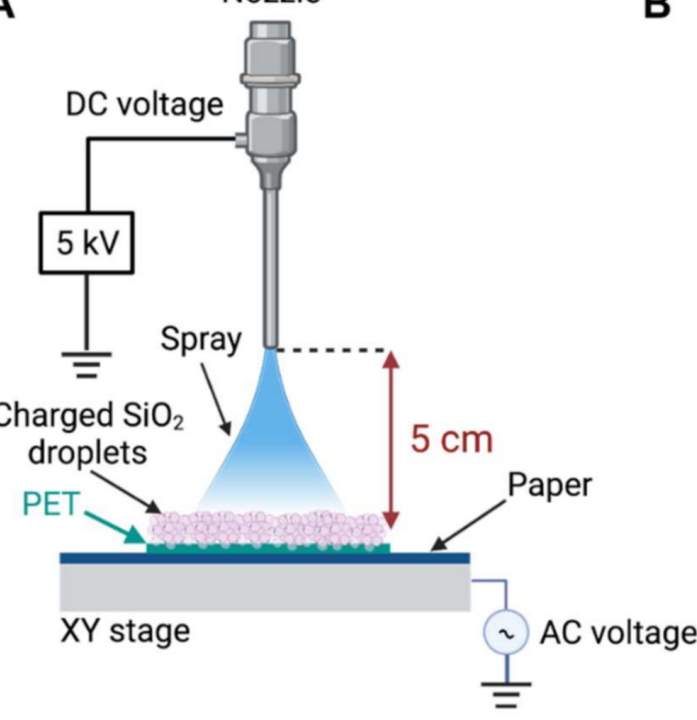

B

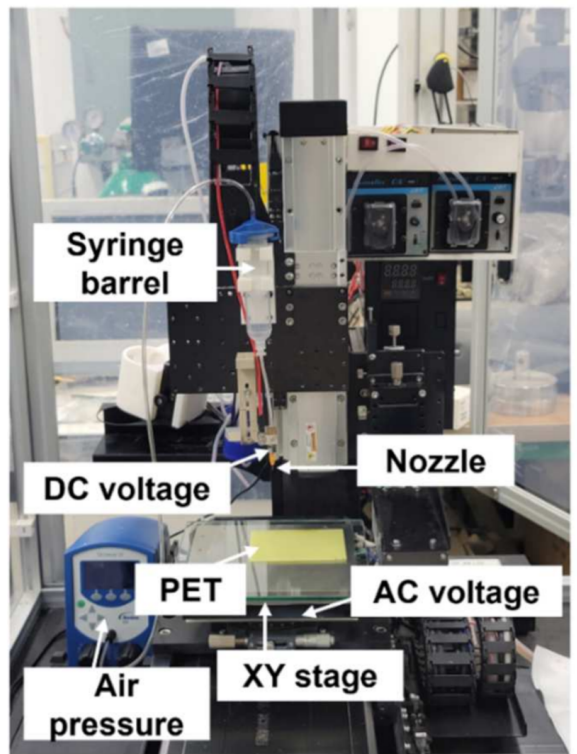

Figure 1. Fabrication and characterization of the electrosprayed $\mathrm{SiO}_{2}$ surface. (A) A schematic illustration of electrospray $\mathrm{SiO}_{2}$-deposited surface fabrication on polyethylene terephthalate (PET) substrate (created with BioRender.com). (B) A photograph of the experimental set-up.

\subsection{Characterization of the $\mathrm{SiO}_{2}$-Deposited Surface by SEM, FTIR, and AFM}

As reported in our previous study, the novel AC-biased electrospray technique could result in high uniformity and homogenous deposition of silica on various substrates including PET, glass, and paper with hydrophobic surface properties [23]. We further confirmed these findings by SEM and FTIR to validate the effectiveness of our novel coating method. SEM analysis was carried out to investigate the morphology of the $\mathrm{SiO}_{2}-$ deposited PET in comparison with that of the plain PET surface. As shown in Figure 2A, the $\mathrm{SiO}_{2}$-deposited PET surface was completely covered by granular and pebbled structures of $\mathrm{SiO}_{2}$ particles without any empty space. In contrast, a smooth topology and no $\mathrm{SiO}_{2}$ particles were observed on the plain PET surface. Additionally, as shown in Supplementary Figure S1 (see Supplementary Materials), cross-sectional SEM images displayed $1.71 \mu \mathrm{m}$ thickness of $\mathrm{SiO}_{2}$ layer on PET substrate. In contrast with the deposited surface, plain PET exhibits no deposition of $\mathrm{SiO}_{2}$, suggesting that the deposition of $\mathrm{SiO}_{2}$ onto PET substrate was successful. We further conducted energy dispersive spectroscopy analysis to assess the chemical compositions of plain PET and $\mathrm{SiO}_{2}$-deposited PET surfaces. The $\mathrm{Si}$ and $\mathrm{Cl}$ atoms were detected only on $\mathrm{SiO}_{2}$-deposited PET because silica and epoxy resin solutions were used as the deposition materials (Figure 2B).

In addition, FTIR analysis was used to determine the functional groups presented on the fabricated surface. A representative spectrogram is shown in Figure $2 \mathrm{C}$ and Supplementary Figure S2. To confirm the effectiveness of the electrospray deposition onto PET films, we characterized the $\mathrm{SiO}_{2}$ powder and compared it with the fabricated surface. Because $\mathrm{SiO}_{2}$ powder was initially mixed with epoxy resin to increase its adhesion on PET surface, the bands at 1293,945 , and $826 \mathrm{~cm}^{-1}$ were shown as characteristic bands for epoxy groups, and bands were presented in $\mathrm{SiO}_{2}$-deposited PET and epoxy resin but not in plain PET surface [24]. Absorption bands at 1071 and $802 \mathrm{~cm}^{-1}$ were presented in the $\mathrm{SiO}_{2}$ powder and on the $\mathrm{SiO}_{2}$-deposited PET and were attributed to $\mathrm{Si}-\mathrm{O}-\mathrm{Si}$ and $\mathrm{Si}-\mathrm{O}$ groups, respectively [25-27]. Moreover, the FTIR spectrum of the plain PET surface showed multiple bands of $\mathrm{C}=\mathrm{O}$ and $\mathrm{C}-\mathrm{H}$ groups at 1712 and $723 \mathrm{~cm}^{-1}$ [28], respectively, as well as C-O groups at 1239 and $1096 \mathrm{~cm}^{-1}$ [29,30]. Furthermore, Si-O-Si and Si-O bands did not appear in the plain PET samples. However, absorption bands at 723, 1096, 1239, and $1712 \mathrm{~cm}^{-1}$ decreased or disappeared because of the electrospray coating. 
A

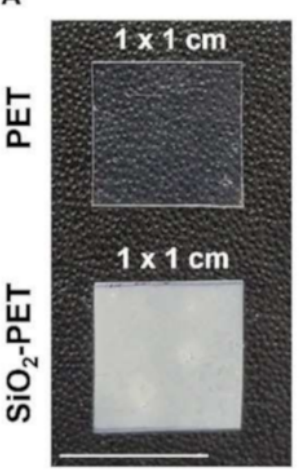

B

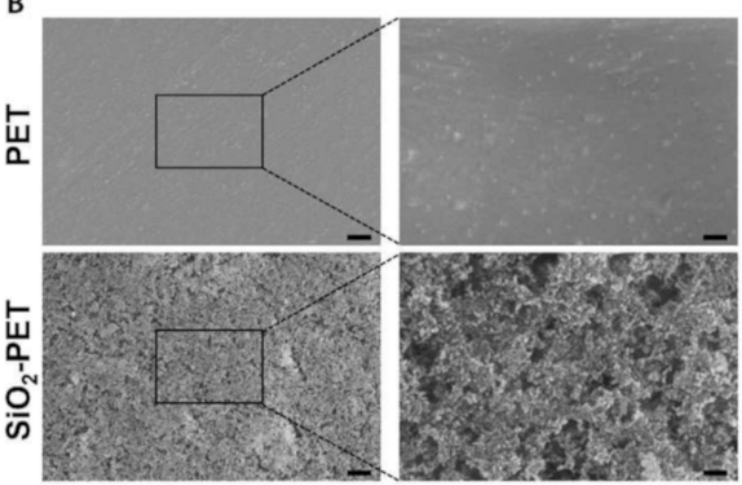

C
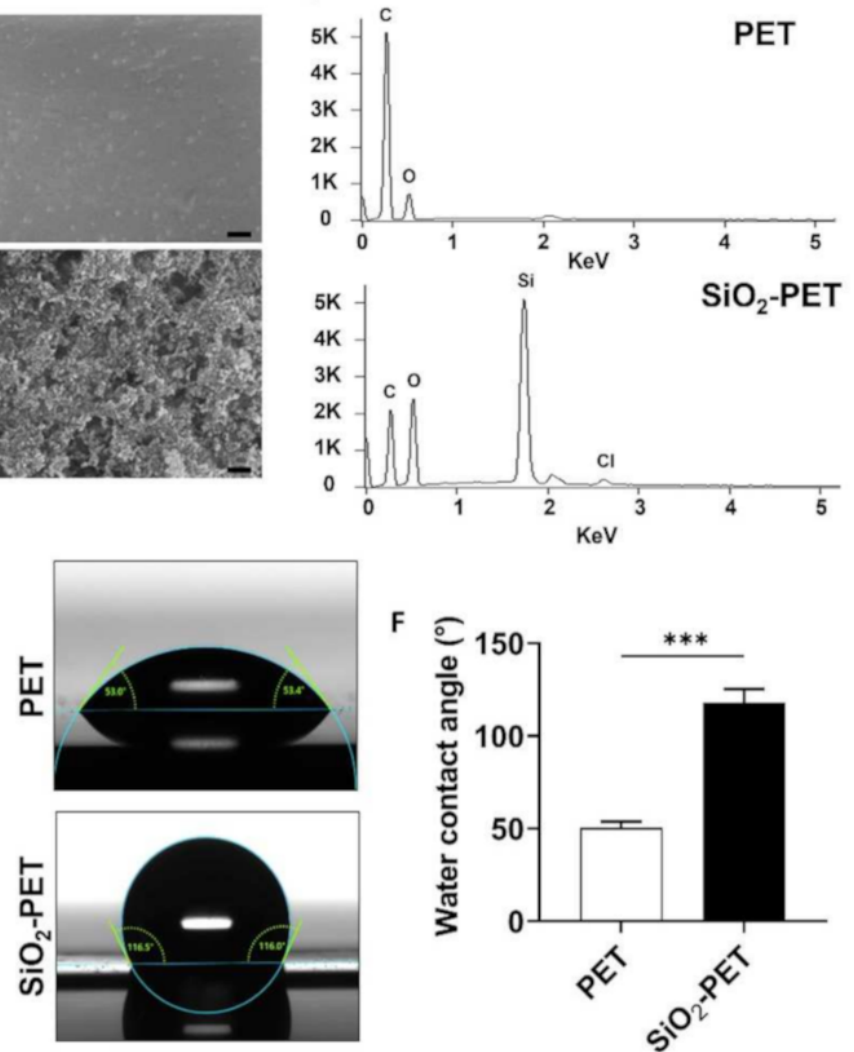

$\mathrm{SiO}_{2}-\mathrm{PET}$

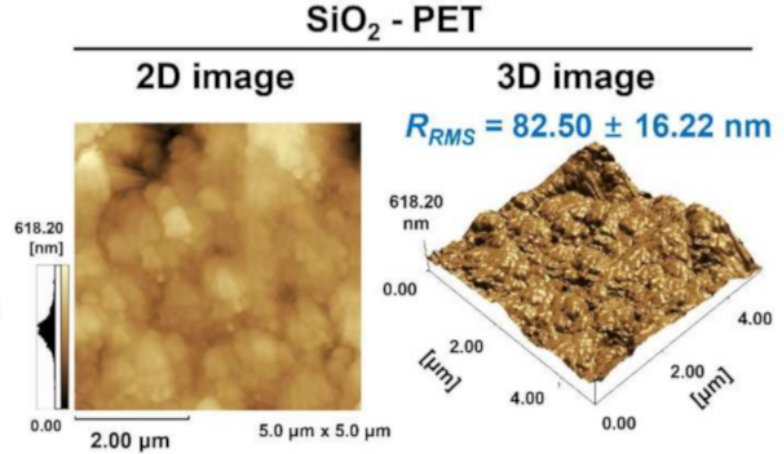

G

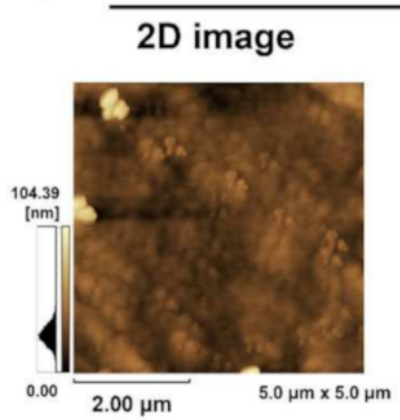

PET

3D image
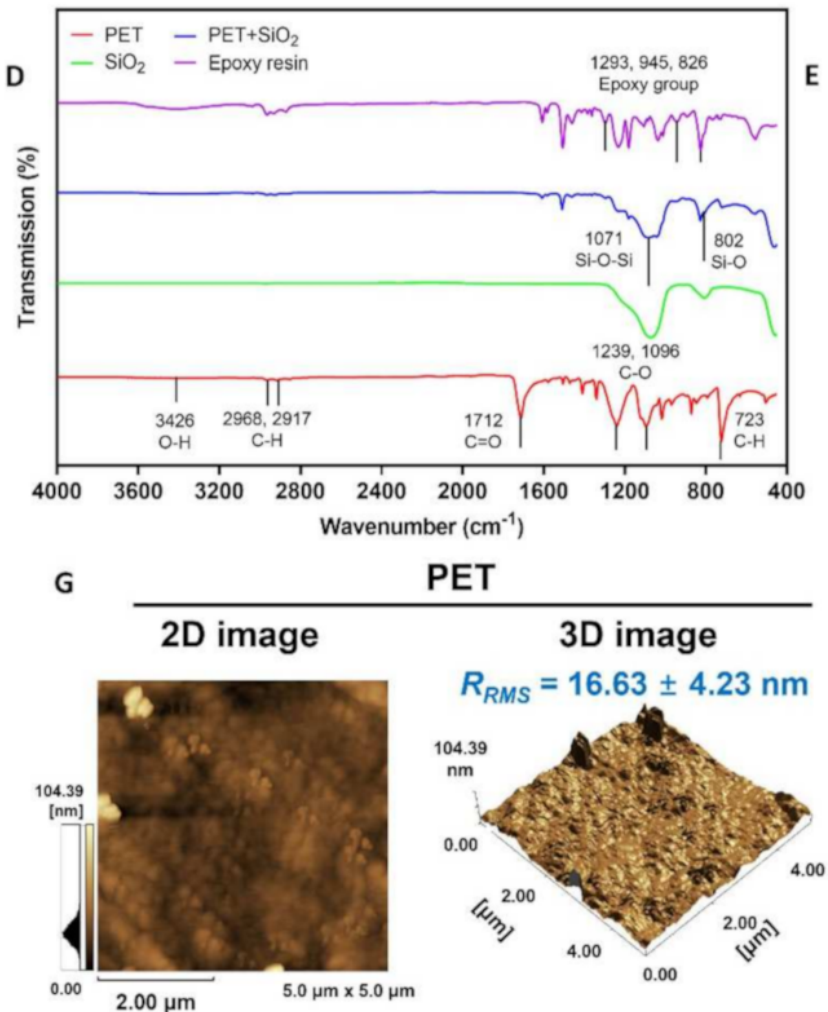

Figure 2. Characterization of the $\mathrm{SiO}_{2}$-electrosprayed surface. (A) Optical images of plain PET and $\mathrm{SiO}_{2}$-deposited PET films (scale bar: $10 \mathrm{~mm}$ ). (B) SEM images of plain PET and $\mathrm{SiO}_{2}$-deposited PET films (scale bar: $2 \mu \mathrm{m}$ (left) and $400 \mathrm{~nm}$ (right)). (C) EDS analysis of PET and $\mathrm{SiO}_{2}$-deposited PET. (D) FTIR analysis PET and $\mathrm{SiO}_{2}$-deposited PET. (E) Water droplets formed on PET and $\mathrm{SiO}_{2}$-deposited PET. (F) Water contact angles of PET and $\mathrm{SiO}_{2}$-deposited PET surfaces. (G) AFM images of plain PET and $\mathrm{SiO}_{2}$-deposited PET films roughness $(n=5),{ }^{* * *} p<0.001$.

Substrate wettability is the primary factor that influences bacterial adhesion; hydrophobic surfaces show reduced bacterial attachment, whereas hydrophilic surfaces promote bacterial adhesion $[14,15]$. In this study, we conducted WCA measurements to evaluate the hydrophobicity of the $\mathrm{SiO}_{2}$-deposited PET surface as compared with that of the plain PET surface. The WCA was calculated at room temperature $\left(20^{\circ} \mathrm{C}\right)$ using an optical contact angle meter. As shown in Figure 2D-F, the water droplet on the plain PET surface was spread, whereas the water droplet on the $\mathrm{SiO}_{2}$-deposited PET was rounded and aggregated. $\mathrm{SiO}_{2}$ deposition on the PET surface exhibited a decrease in water wettability with a higher WCA value $\left(118.1^{\circ} \pm 7.2^{\circ}\right)$ compared with the plain PET sample $\left(50.3^{\circ} \pm 3.5^{\circ}\right)$ (Supplementary Figure S3). We also performed a dynamic contact angle test to evaluate 
the degree of stickiness of both plain PET and $\mathrm{SiO}_{2}$-deposited PET surfaces. Additionally, higher water repellency was observed on the $\mathrm{SiO}_{2}$-deposited PET sample as water droplets easily rolled off from the surface at $45^{\circ}$ inclination. Meanwhile, the plain PET sample with lower WCA value allowed the spreading of water droplets and slow movement even on the tilted surface (Supplementary Information Video S1 and S2). These findings indicate that surface hydrophobicity was achieved by the electrosprayed $\mathrm{SiO}_{2}$ deposition.

As deposition of coating materials has been reported to affect surface topography [31-34], we performed AFM to analyze the roughness of our fabricated surface. As shown in Figure 2G, on one hand, the deposition of $\mathrm{SiO}_{2}$ onto PET substrate showed root-meansquare roughness $\left(R_{R M S}\right)$ and average roughness $\left(R_{a}\right)$ values of $82.50 \pm 16.22 \mathrm{~nm}$ and $65.15 \pm 15.26 \mathrm{~nm}$, respectively. Conversely, the plain PET sample showed $R_{R M S}=16.63$ $\pm 4.23 \mathrm{~nm}$ and $R_{a}=11.65 \pm 2.87$, which were significantly lower than those of the $\mathrm{SiO}_{2}$-deposited PET sample. These results implied that the deposition of $\mathrm{SiO}_{2}$ onto PET substrate increased surface roughness as well as hydrophobicity, which might be able to synergistically contribute to antibacterial properties.

\subsection{Antibacterial Properties of $\mathrm{SiO}_{2}$-Deposited Surfaces}

Here, we further hypothesized that the hydrophobicity of silica may prevent bacterial adhesion to the surface. To determine the antibacterial properties of our hydrophobic fabricated surface, we performed antibacterial assays using E. coli and S. aureus as model bacteria. As shown in Figure 3, both E. coli and S. aureus were initially cultured on LuriaBertani (LB) agar, then plain PET and $\mathrm{SiO}_{2}$-deposited PET samples sized $1 \times 1 \mathrm{~cm}$ were directly placed on top of the agar to allow bacterial adhesion on the surfaces. The amount of adhered bacteria were measured from the surfaces of both plain PET and $\mathrm{SiO}_{2}$-deposited PET films; after transferring the films to LB broth tubes and applying vortex, the detached bacteria from the surfaces were measured, whereas both E. coli and S. aureus grown on the surface of agar were used as positive controls (Figure 3).

\section{E. coli or S. aureus}
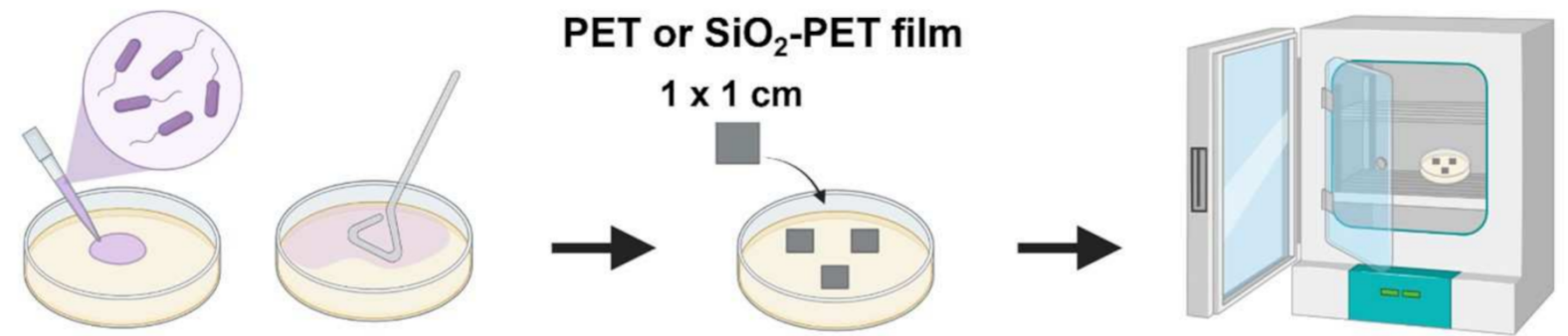

Inoculation and spreading of bacteria

Incubation at $37^{\circ} \mathrm{C}$ for $12 \mathrm{~h}$

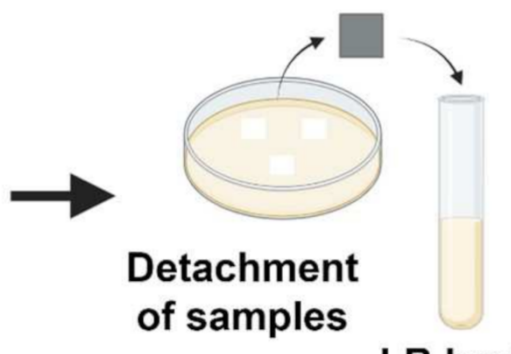

LB broth

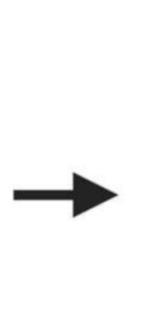

\section{Vortex for $1 \mathrm{~min}$}
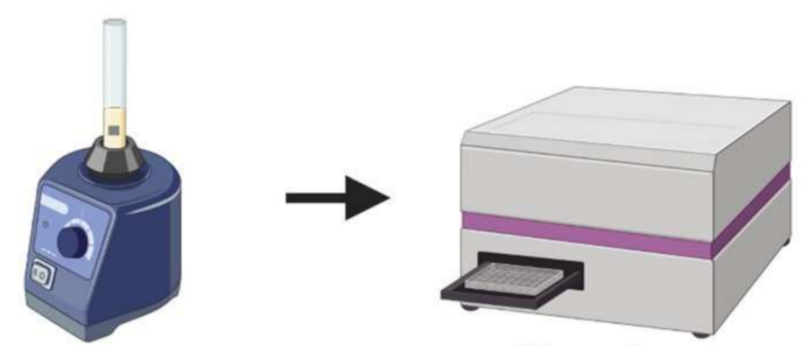

Absorbance measurement $\left(O D_{600}\right)$

Figure 3. A schematic illustration of the antibacterial assay-created with BioRender.com (accessed on 25 October 2021). 
As shown in Figures 4A and 5A, both E. coli and S. aureus were able to grow rapidly on the surface of LB agar that was not covered by films for $12 \mathrm{~h}$ of incubation. After detaching adhered bacteria (E. coli and S. aureus) on to the samples, the $\mathrm{SiO}_{2}$-deposited PET suspension had the lowest turbidity among all groups, whereas the bacterial suspension from the PET sample was more opaque than that of the $\mathrm{SiO}_{2}$-deposited PET. Moreover, the agar-grown E. coli and S. aureus (positive control) suspensions appeared to be turbid compared to the other groups (Figures $4 \mathrm{~B}$ and $5 \mathrm{~B}$ ). This qualitative observation was further confirmed by an absorbance measurement, which is shown in Figures 4C and 5D. Compared to the plain $\mathrm{PET}$ and $\mathrm{SiO}_{2}$-deposited PET samples, agar-grown bacteria (positive control) displayed the highest absorbance with $\mathrm{OD}_{600}$ values of $0.67 \mathrm{~A}$ and $0.60 \mathrm{~A}$ for E. coli and S. aureus, respectively. The $\mathrm{OD}_{600}$ value of adhered E. coli on to $\mathrm{SiO}_{2}$-deposited PET was 0.12 , whereas plain PET sample showed higher bacterial adhesion (0.37) (Figure 4C). The same trend was also evidenced for $S$. aureus as $\mathrm{SiO}_{2}$-deposited PET showed the lowest $\mathrm{OD}_{600}$ value of 0.13 compared to plain PET samples (0.36) (Figure 5C). Based on these absorbance results, the inhibition percentages of $\mathrm{SiO}_{2}$-deposited PET against both bacteria were quite similar, with inhibition percentages of $66.30 \%$ and $64.09 \%$ for E. coli and S. aureus, respectively, suggesting that our fabricated surfaces are effective in inhibiting both Gram-positive and Gram-negative bacterial adhesion.

\section{A Before detachment}

After detachment

B
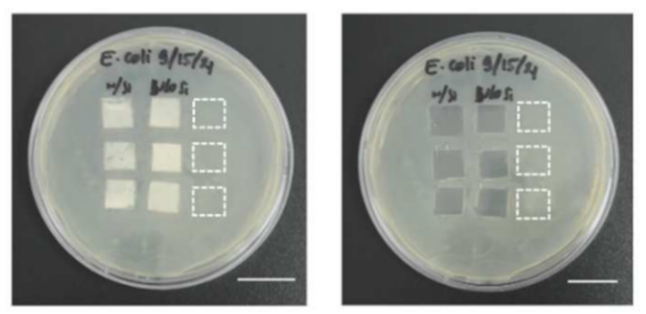

E. coli on Agar

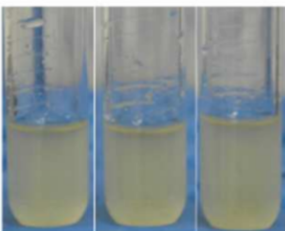

E. coli on PET

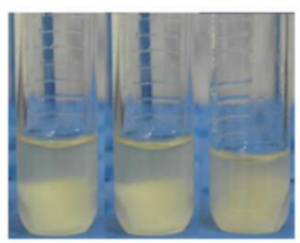

\section{E. coli on $\mathrm{SiO}_{2}-\mathrm{PET}$}

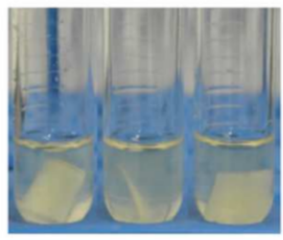

C

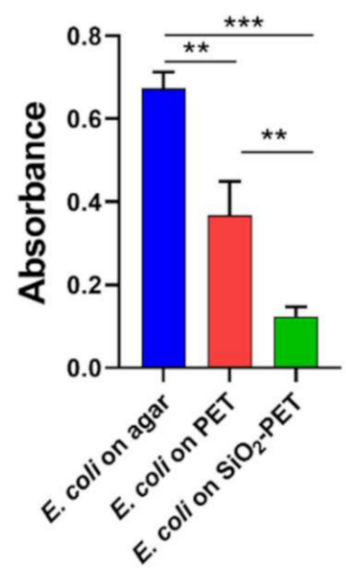

D

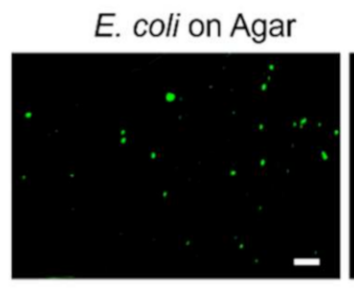

\section{E. coli on PET}

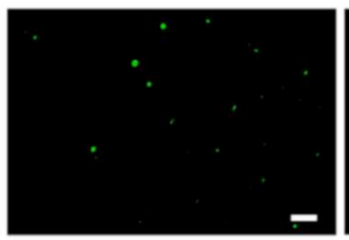

E. coli on $\mathrm{SiO}_{2}$-PET

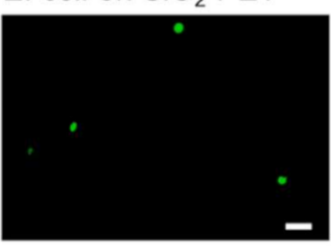

Figure 4. Assessment of the antibacterial properties of electrosprayed $\mathrm{SiO}_{2}$ films against E. coli. (A) Images of agar plates before and after film detachment (scale bar: $20 \mathrm{~mm}$ ). (B) Images of detached films and agar in LB broth after vortexing for $1 \mathrm{~min}$. (C) Quantitative analysis of the detached films based on absorbance at $600 \mathrm{~nm}\left(\mathrm{OD}_{600}\right) .{ }^{* *} p<0.01,{ }^{* * *} p<0.001$. (D) Fluorescence images of live E. coli on the surface (scale bar: $200 \mu \mathrm{m}$ ). 
A

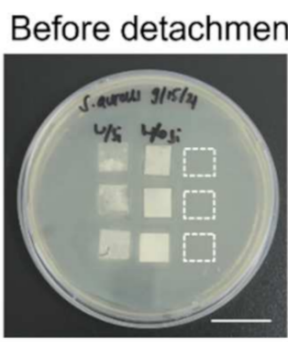

B
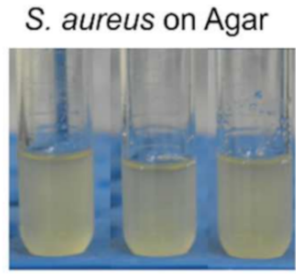
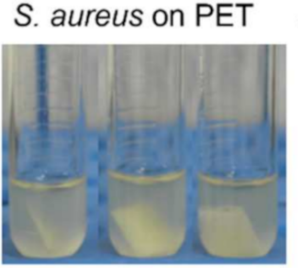

S. aureus on $\mathrm{SiO}_{2}-\mathrm{PET}$

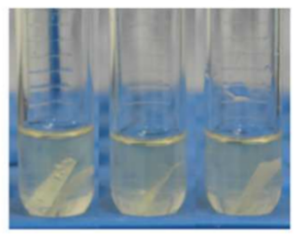

C

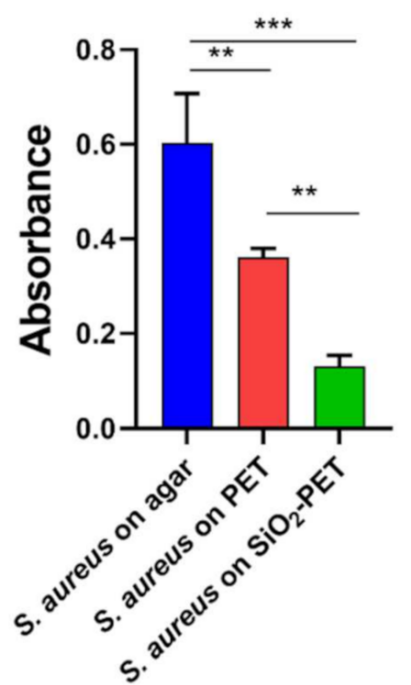

D S. aureus on Agar
S. aureus on PET

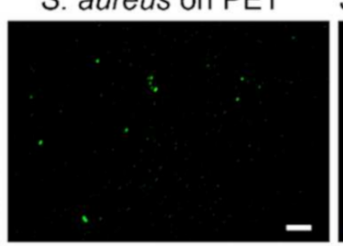

S. aureus on $\mathrm{SiO}_{2}$-PET
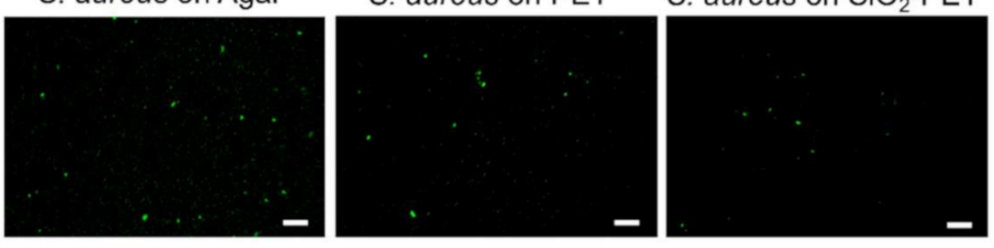

Figure 5. Assessment of the antibacterial properties of electrosprayed $\mathrm{SiO}_{2}$ films against S. aureus. (A) Images of agar plates before and after film detachment (scale bar: $20 \mathrm{~mm}$ ). (B) Images of detached films and agar in LB broth after vortexing for $1 \mathrm{~min}$. (C) Quantitative analysis of detached films based on absorbance at $600 \mathrm{~nm}\left(\mathrm{OD}_{600}\right){ }^{* *} p<0.01,{ }^{* * *} p<0.001$. (D) Fluorescence images of live S. aureus on the surface (scale bar: $200 \mu \mathrm{m})$.

Additionally, because bacterial aggregation on the surface is a precursor of biofilm formation [1], we conducted fluorescence imaging for both E. coli and S. aureus to observe a reduction in bacterial aggregates and their spatial distribution onto the plain and $\mathrm{SiO}_{2}$-deposited PET samples. The visualization of E. coli on the surface was performed without any staining procedure as we used the GFP-tagged E. coli strain. Consistent with the quantitative absorbance results, on the one hand, the E. coli grown on agar in the same area as the samples (positive control) showed the highest number of viable cells (Figure 4D). Conversely, $\mathrm{SiO}_{2}$-deposited PET demonstrated a significant reduction of E. coli attachment, while plain PET surface allowed bacterial attachment after $12 \mathrm{~h}$ of culture. For the visualization of live S. aureus, we performed live/dead staining and similar to the $E$. coli results, significantly increased numbers of $S$. aureus colonies were observed in the positive control, whereas $\mathrm{SiO}_{2}$-deposited PET showed the least adhesion among all the groups (Figure 5D). Together, these results implied that the electrospray deposition of $\mathrm{SiO}_{2}$ onto PET surface could limit bacterial adhesion.

\subsection{Cytotoxicity Test for In Vitro Cell Culture}

To assess whether deposited $\mathrm{SiO}_{2}$ has a detrimental effect on cell viability, we conducted an MTT assay and analyzed cell viability after incubating human dermal fibroblasts for $24 \mathrm{~h}$ in media preconditioned with plain PET and $\mathrm{SiO}_{2}$-deposited PET samples as compared with growth medium (Figure 6). In this study, we evaluated the cytotoxicity of plain PET and $\mathrm{SiO}_{2}$-deposited PET samples against human dermal fibroblasts (HDFs) because skin is the body's largest external organ and a host organ for diverse microorganisms, including bacteria, and some of them, such as S. aureus and Streptococcus pyogenes, are 
pathogens that can cause infections [35,36]. As shown in Figure 6, there were no significant changes in $\mathrm{HDF}$ viability after $24 \mathrm{~h}$ of exposure in PET and $\mathrm{SiO}_{2}$-deposited PET conditioned media, with cells showing $95.87 \%$ and $93.75 \%$ viability, respectively.

A

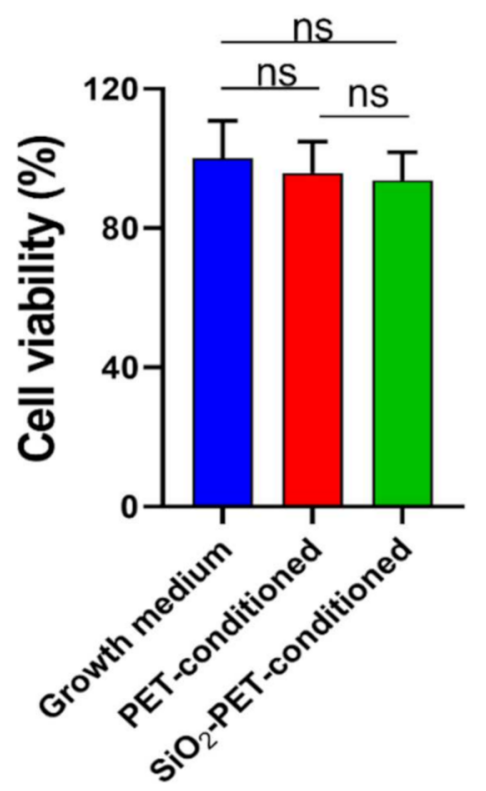

B
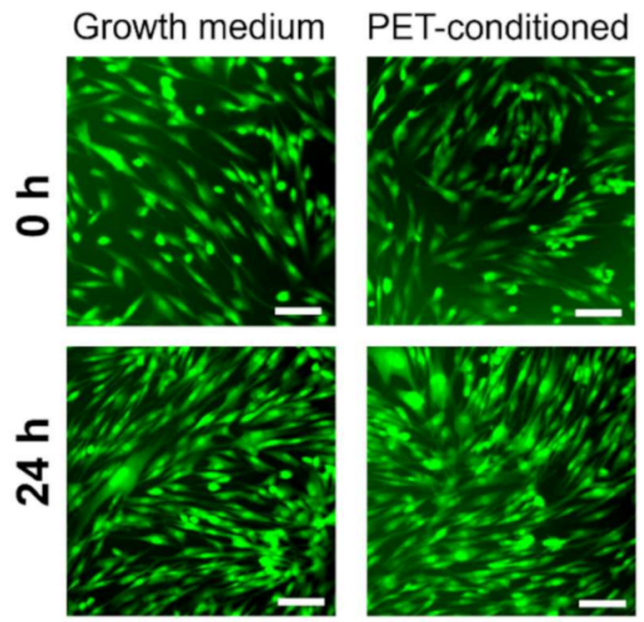

\section{$\mathrm{SiO}_{2}$-PET-conditioned}
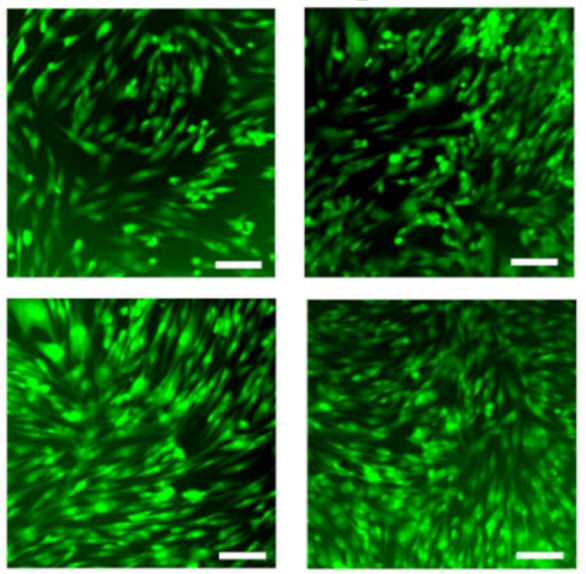

Figure 6. Cytotoxicity tests for $\mathrm{PET}$ and $\mathrm{SiO}_{2}$-deposited PET using human dermal fibroblasts (HDFs). (A) Cell viability after $24 \mathrm{~h}$ growth. (B) Fluorescence images of live/dead staining of HDFs at passage after $0 \mathrm{~h}$ and $24 \mathrm{~h}$ of incubation in growth medium or conditioned medium (scale bar: $100 \mu \mathrm{m}$ ). "ns" indicates that there is no statistical difference.

In addition to the MTT assay, these findings were further corroborated by live/dead staining results. As shown in Figure 6B, live HDF cells were visualized by green fluorescence and cell morphology showed no signs of cell death and morphological changes due to any substances released from the PET and $\mathrm{SiO}_{2}$-deposited PET films. Moreover, the cells were able to grow rapidly in the presence of the conditioned medium for $24 \mathrm{~h}$. Therefore, these qualitative and quantitative data are evidence for the highly biocompatible properties of $\mathrm{SiO}_{2}$-electrosprayed surface.

\section{Discussion}

Silica $\left(\mathrm{SiO}_{2}\right)$ is non-toxic, highly flexible, and chemically stable and exhibits good biocompatibility and bio-inert properties [37]. In addition to biocompatibility, silica also displays bioconjugation properties, and silica nanoparticles are commonly introduced as coating materials [38]. Thus, various approaches have been used in biomedical, diagnostic, and therapeutic applications, particularly for the coating of various medical devices $[18,19,39]$. Furthermore, Wang et al. [19] developed a silica-based antibacterial coating for dental implants and showed that silica nanoparticles and gentamycin could be successfully incorporated without any risk of infection, demonstrating that silica-based materials are applicable as a drug delivery system.

The fabrication of hydrophobic surfaces has been developed using numerous techniques, such as lithography, etching, templating, sol-gel method, layer-by-layer deposition, and spray coating [13]. Among these options, electrospray-based coating techniques have been widely used for coating thin films with nanomaterials by applying a high voltage known as the electrospray technique, resulting in charged droplet production from the aerosol phase $[16,39]$. This method has the advantage of creating a highly uniform coating on a wide variety of surfaces through an interplay between the nanoparticle deterministic velocity and thermal velocity due to Brownian motion [40]. Furthermore, the electrospray 
technique can be easily scaled up for industrial processes [41]. In contrast to the conventional electrospray method, we successfully developed a novel technique for generating $\mathrm{SiO}_{2}$-deposited surfaces by applying an alternating current (AC) voltage under the substrate holder (Figure 1). According to our preliminary studies, the effectiveness of this method was demonstrated by an increase in the coating layer thickness to $1.91 \mu \mathrm{m}$, implying that the $\mathrm{AC}$ voltage yielded a high uniformity and deposition rate. Furthermore, substrates with a coating thickness of $1 \mu \mathrm{m}$ exhibit hydrophobic properties and are capable of ensuring reliability in harsh environments [23]. In the same study, we also assessed the stability and durability of $\mathrm{SiO}_{2}$-deposited surfaces by sandpaper abrasion, tape peeling, and UV irradiation tests as well as immersion in a corrosive liquid. The stability of $\mathrm{SiO}_{2}$ deposited samples was shown by no significant changes of water contact angle values upon UV light exposure for $24 \mathrm{~h}$ and after tape peeling and multiple abrasion cycles. Meanwhile, the durability test was performed by immersing the samples in hydrochloric acid $(\mathrm{HCl})$ for $20 \mathrm{~min}$. Although the water contact angle values gradually decrease in an immersion time-dependent manner, we observed only a slight (less than 3\%) decrease in WCA when samples were exposed for $10 \mathrm{~min}$ [23].

Previously, various types of superhydrophobic surfaces, such as window glass and solar cell panels, were developed for self-cleaning applications based on their ability to weaken bacterial adhesion [42]. The wettability of a surface is determined by the WCA value; a surface is considered hydrophobic if the WCA is in the range of $90-150^{\circ}$ and is defined as superhydrophobic when the WCA is greater than $150^{\circ}$ [43]. Although silicon itself is not inherently antibacterial, $\mathrm{SiO}_{2}$-deposited surfaces can effectively inhibit bacterial adhesion owing to their hydrophobic properties, as described previously [44]. Additionally, silica $\left(\mathrm{SiO}_{2}\right)$ possesses alkyl or polydimethylsiloxane chains, which contribute to hydrophobicity [45]. Furthermore, our findings supported our initial hypothesis that $\mathrm{SiO}_{2}$-deposited surfaces, which had WCA values of $118.1^{\circ} \pm 7.2^{\circ}$, had lower bacterial adhesion than plain PET samples (Figure 2E,F, Figure 4B-D and Figure 5B-D). These results were further supported by numerous studies showing lower bacterial adhesion on surfaces with higher WCA values [14-16,46,47]. Similar to our findings, Li et al. [47] demonstrated the fabrication of superhydrophobic silicone rubber (SR) surfaces using silica powder through a simple process and low-cost preparation based on the high-temperature vulcanized method. The results showed that the $\mathrm{SiO}_{2} / \mathrm{SR}$ sample still had excellent bouncing properties when the temperature was increased to $200{ }^{\circ} \mathrm{C}$. The superhydrophobic properties of the $\mathrm{SiO}_{2}$ deposited surfaces were then quantified, revealing a WCA value of $160.3^{\circ}$. In addition, the antibacterial properties were also affected by the smooth surface topology of the film, resulting in the weakening of cell-surface interactions, regardless of the treatment, and thereby leading to unstable bacterial adhesion and detachment owing to mechanical stress, particularly during the rinsing process [15]. The anti-adhesive properties of $\mathrm{SiO}_{2}$-deposited surface was also confirmed by a roll-off angle test, indicating the non-sticky properties of the hydrophobic surface as water droplets were unable to spread and immediately slid off at $45^{\circ}$ of inclination, whereas the plain PET surface showed that the water droplets were at pinning state as they could not easily roll off from the surface (Supplementary Information Video S1 and S2). A similar study by Schneider et al. [48] also displayed the high water repellency of silicon-deposited superhydrophobic surfaces on both static and dynamic contact angle tests, which can be explained by a high friction during the movement that increases driving force and surface tension of the liquid.

Furthermore, the association between surface topography and bacterial adhesion has also been reported as several studies have shown a reduction of bacterial growth when surface roughness is increased on the surface [31-34]. Similarly, our current study demonstrated that the deposition of $\mathrm{SiO}_{2}$ onto PET substrate increases the surface roughness ( $R_{R M S}$ value of $82.50^{\circ} \pm 16.22^{\circ} \mathrm{nm}$ and $R_{a}$ value of $65.15 \pm 15.26 \mathrm{~nm}$, respectively), resulting in an increase in the WCA value to more than $90^{\circ}$, and both increased surface roughness and increased hydrophobicity of synergistically $\mathrm{SiO}_{2}$-PET substrate could reduce the bacterial adhesion on the surface (Figure 2E-G, Figure 4B-D and Figure 5B-D). This phenomenon is 
caused by the increased roughness on a hydrophobic surface that enhances air entrapment within the micro- or nano-structures, resulting in a lower penetration ability and free movement of the liquids; thus, the bacteria can be easily removed and detached from the surface [31]. Another similar study by Startek et al. [32] reported that the deposition of $\mathrm{SiO}_{2}$ with ten fluorinated carbons in the alkyl chain $\left(-\mathrm{CF}_{10}\right)$ using spin-coating method onto PET substrate exhibits $R_{R M S}$ and $R_{a}$ values of 63.1 and $78.3 \mathrm{~nm}$, respectively and increases the WCA value to $113^{\circ}$. In order to achieve superhydrophobicity, an increase of surface roughness is needed to reach a higher $R_{R M S}$ value, as reported by Ozkan et al. [33], who successfully fabricated a Cu-nanoparticles-coated polydimethylsiloxane (PDMS) substrate with $\mathrm{WCA}=151^{\circ}$ and $R_{R M S}=230 \mathrm{~nm}$. In their study, the superhydrophobic surface was able to weaken $E$. coli adhesion in just $15 \mathrm{~min}$ and $S$. aureus in $1 \mathrm{~h}$. The relationship among surface roughness, hydrophobicity, and antibacterial properties was also shown by Svirinosky et al. [34], displaying an improvement of WCA value as surface roughness increases when different coating materials were incorporated onto the substrate that promotes the antibacterial functionality.

The antibacterial activity of silica coating was previously reported by Privett et al. [44]. In their study, silica colloids were applied for the fabrication of superhydrophobic surfaces, and the anti-adhesive ability was confirmed by the significant reduction of $S$. aureus and $P$. aeruginosa adhesion on the surface, with inhibition rates greater than $98 \%$ for both bacteria. In another similar study, Kaya et al. [49] successfully developed a drug carrier by utilizing silica hydrogels, and further investigation revealed its antibacterial activity against E. coli, P. aeruginosa, and S. aureus. Hence, our study is focused on the investigation of the antibacterial properties of silica-deposited PET that is fabricated by a novel electrospray technique. Based on the results, our silica fabricated surfaces were effective in inhibiting $66.30 \%$ E. coli and $64.09 \%$ S. aureus adhesion (Figures $4 \mathrm{C}$ and $5 \mathrm{C}$ ). These results were also supported by the fluorescence images that showed low numbers of attached bacteria on silica-deposited surfaces (Figures 4D and 5D). Hasan et al. [50] previously reported that more than $85 \%$ of bacterial inhibition rate could be achieved by a surface with 80-300 nm of $R_{a}$ and 110-380 nm of $R_{R M S}$ values. As our fabricated surface displays both $R_{a}$ and $R_{R M S}$ values outside of these ranges, this might lower the antibacterial properties as it does not exhibit a WCA value greater than $150^{\circ}$ (Figure $2 \mathrm{E}-\mathrm{G}$ ). Additionally, superhydrophobicity improves the bacterial inhibition rate to more than $90 \%$ as reported by numerous studies [12,34,45,51,52]. Although the antibacterial properties of electrosprayed $\mathrm{SiO}_{2}$ surfaces have not yet been extensively studied, several studies have demonstrated the effectiveness of electrospray coating at inhibiting bacterial adhesion using different materials, such as titania $\left(\mathrm{TiO}_{2}\right)[16,17]$. In general, surfaces with hydrophobic properties show reduced adhesion of bacteria compared with hydrophilic surfaces, which allow bacteria to bind [14]. A study conducted by Jalvo et al. [16] demonstrated that electrosprayed $\mathrm{TiO}_{2}$ coatings could inhibit biofilm formation by $S$. aureus in water filtration ceramic membranes. Irradiation treatment of $\mathrm{TiO}_{2}$-functionalized surfaces successfully inhibited S. aureus biofilm production with a 99\% removal rate. Another similar study by Yoon et al. [17] also showed the antibacterial properties of electrosprayed $\mathrm{TiO}_{2}$-functionalized surfaces towards E. coli. The antibacterial test was conducted under ultraviolet radiation, and the effect was observed at an annealing temperature of $500{ }^{\circ} \mathrm{C}$, showing a $93 \%$ reduction in E. coli growth.

Bacterial morphology is an essential factor that can affect bacterial adhesion during surface colonization. Indeed, in a previous study by Duvernoy et al., rod-shaped bacteria, such as E. coli and Pseudomonas aeruginosa, were shown to exhibit a strong adhesive force owing to their asymmetric microcolony shape [51]. Another approach by Hemmatian et al. [15] also showed a higher adherence of E. coli on hydrophobic surfaces compared with $S$. aureus, a circular-shaped bacterium, because rod-shaped bacteria have a larger interactive surface area. Furthermore, the cell wall structure and chemical composition are also involved in bacterial adhesion on the surface [52]. The bacterial cell wall is composed of peptidoglycan, which is structured around a poly- $(N$-acetylglucosamine- $N$-acetylmuramic acid) backbone [53]. Gram-positive bacteria differ from Gram-negative bacteria because of 
their thick peptidoglycan layer and the absence of lipopolysaccharide (LPS) [54]. Stronger inhibition of viable Gram-negative bacteria has also been reported in some studies $[55,56]$. For example, Lima et al. [55] revealed a higher antibacterial activity of chitosan-based hydrophobic surfaces against $P$. aeruginosa than $S$. aureus, which may be explained by the presence of phosphate groups in LPS from Gram-negative bacteria, enhancing the negative charge and promoting attraction to the positively charged chitosan surface. In contrast to previous reports, our findings revealed no significant differences in the inhibition of Gram-positive and Gram-negative bacterial adhesion, suggesting that the fabricated silica coating synthesized using our novel electrospray method may be effective for preventing the adhesion of both Gram-positive and Gram-negative bacteria. Moreover, bactericidal materials, such as nanomaterials, metal ions, and antimicrobial compounds, were not attributed to the fabricated surface, indicating that the biocompatibility and long-term stability were still well-maintained $[57,58]$.

High biocompatibility of our fabricated surface was observed by more than $90 \%$ HDF cells under $24 \mathrm{~h}$ exposure of extracted coating materials (Figure 6A). These findings were consistent with the results of a previous study by Pillai et al. [59] who performed the same extraction method and showed that cell viability remained at greater than $80 \%$; thus, these findings suggested that the coating materials did not diffuse out into the growth medium and exhibited excellent biocompatibility without toxicity in HDFs. In addition, our findings were similar to those of Dulski et al. who focused on the development of silver-silica coating as a functional biomaterial surface [60]. Based on their results, the fabricated surface could significantly inhibit $E$. coli and $S$. aureus biofilm formation and showed high biocompatibility with HDFs, yielding no dead or deformed cells after $72 \mathrm{~h}$ in morphological examinations. Owing to their biocompatibility, nanoparticles are often incorporated into $\mathrm{SiO}_{2}$ coatings to improve the mechanical stability of the material [61]. Navarro-Palomares et al. fabricated a surface coating by incorporating 15 and $30 \mu \mathrm{g} / \mathrm{mL}$ zinc oxide $(\mathrm{ZnO})$ into silica and reported that the resulting product yielded over $75 \%$ viability in HeLa cells [62]. Thus, the $\mathrm{SiO}_{2}$ coating is not only biocompatible, but also exhibits biodegradable properties owing to its high stability under physical conditions. Nevertheless, some studies have also evaluated the potential cytotoxic effects of $\mathrm{SiO}_{2}$ nanoparticle coatings on human cells [63]. The results showed that the potential toxic effects do not originate from silica itself, but are a result of cooperation with co-nanoparticles, such as $\mathrm{ZnO}$ and $\mathrm{TiO}_{2}$, which could cause cell death at high concentrations by promoting the breakdown of the mitochondrial membrane [64]. Hence, our fabricated surface is a promising coating material for biomedical devices owing to its antibacterial properties and excellent biocompatibility.

\section{Materials and Methods}

\subsection{Preparation of Deposition Materials}

The deposition material used for surface fabrication was a mixture of silica and epoxy solutions. Fumed silica nanoparticles (Aerosil R 972) with a particle size of $16 \mathrm{~nm}$ were kindly donated by Evonik Industries (Essen, North Rhine-Westphalia, Germany), and epoxy resin (poly-[bisphenol A-co-epichlorohydrin]) and other reagents, such as 4,4-methylenebis [2-chloroaniline]) (a curing agent) and 2-butoxyethanol reagent, were purchased from Sigma-Aldrich (South Korea). To make the epoxy resin solution, $0.40 \mathrm{~g}$ epoxy resin (in pellet form), $0.08 \mathrm{~g}$ curing agent, and $9.52 \mathrm{~g}$ 2-butoxyethanol were mixed using a magnetic stirrer for $8 \mathrm{~h}$ at $70{ }^{\circ} \mathrm{C}$. The silica solution was prepared by mixing $0.40 \mathrm{~g}$ fumed silica with $9.60 \mathrm{~g}$ 2-butoxyethanol using a magnetic stirrer for $2 \mathrm{~h}$ at room temperature. Both epoxy resin and silica solutions were mixed in a 1:1 ratio using a magnetic stirrer for $1 \mathrm{~h}$ at room temperature, followed by sonication for $5 \mathrm{~min}$.

\subsection{Electrospray-Based Silicon Deposition onto PET Films}

A schematic illustration of the experimental setup is shown in Figure 1. Fabrication of the electrosprayed $\mathrm{SiO}_{2}$ surface was performed as reported in our previous study and we used this pre-optimized method in order to deposit $\mathrm{SiO}_{2}$ onto PET substrate with $\sim 2 \mu \mathrm{m}$ 
of thickness [23]. The deposition material was applied by $2 \mathrm{kPa}$ air pressure to a syringe needle with a diameter of $150 \mu \mathrm{m}$. A $5 \mathrm{kV}$ DC voltage was then applied from a power supply (SHV30R; Conver Tech, Gwangmyeong-si, Gyeonggi-do, Korea) to create an electric field and electrical charge in the liquid. To increase the uniformity of silica deposition, the PET film was placed at a distance of $5 \mathrm{~cm}$ from the nozzle tip, and an AC voltage of $3 \mathrm{kHz}$ and $800 \mathrm{~V}$ was applied to the substrate holder. The AC signal was generated using an arbitrary function generator (Agilent 33220A; Agilent Technologies, Santa Clara, CA, USA), and the signal was then amplified using a high-voltage amplifier (Model 2220; Trek, Lockport, NY, USA). For better surface coverage, the distance between swaths was set to $0.5 \mathrm{~cm}$, and the nozzle was moved in a horizontal grid motion with a scanning speed of $2 \mathrm{~mm} / \mathrm{s}$. The experiment was conducted at room temperature $\left(25^{\circ} \mathrm{C}\right)$. After the entire process was completed, the PET film was placed on a hot plate (SP131320-33; Thermo Scientific, Waltham, MA, USA) and annealed at $120^{\circ} \mathrm{C}$ for $1 \mathrm{~h}$.

\subsection{Surface Characterization by FTIR, SEM, and AFM}

The FTIR spectra of the epoxy resin, PET film, $\mathrm{SiO}_{2}$ powder, and $\mathrm{SiO}_{2}$-deposited PET film were analyzed by an Attenuated Total reflectance (ATR) technique using an FTIR spectrometer (Frontier; Perkin Elmer, Waltham, MA, USA) with a spectral width ranging from 450 to $4000 \mathrm{~cm}^{-1}$ at a spectral resolution of $1 \mathrm{~cm}^{-1}$, and the surface of the electrosprayed $\mathrm{SiO}_{2}$ deposition of PET films was examined using SEM (SIGMA 500; Carl Zeiss, Jena, Germany). Briefly, the specimens were gradually dehydrated using a graded series of ethanol solutions. After the specimens were completely dried, they were platinum coated using a sputter coater (E-1030; Hitachi, Tokyo, Japan) for $40 \mathrm{~s}$ prior to SEM imaging. The surface roughness of the PET film and $\mathrm{SiO}_{2}$-deposited PET film were evaluated by atomic force microscopy (AFM) (SPM 9700, Shimadzu, Japan) and root-meansquare roughness $\left(R_{R M S}\right)$ and average roughness $\left(R_{a}\right)$ were measured from the five random spots (scan area of $5 \times 5 \mu \mathrm{m}$ ) by operating in a dynamic mode.

\subsection{Contact Angle Measurement and Roll-Off Angle Test}

The WCA values of the specimens were measured using the sessile drop method at $20^{\circ} \mathrm{C}$ using a contact angle meter (KRUSS DSA30; Hamburg, Germany). A $5 \mu \mathrm{L}$ droplet of distilled water was placed on the surface of the samples. All samples were evaluated at four and five different spots on $\mathrm{SiO}_{2}$-deposited PET and plain PET surfaces, respectively, and the results are presented as means \pm standard deviations. To further confirm the anti-adhesive properties of the fabricated surfaces, roll-off angle test was performed by applying drop-by-drop water onto tilted-samples with an inclination angle of $\delta=45^{\circ}$ as previously described [65].

\subsection{Bacterial Strains and Culture Conditions}

Gram-positive bacteria (S. aureus KCTC3881) and Gram-negative bacteria (E. coli ATCC25922-GFP) were used to evaluate the antibacterial properties of the plain PET and $\mathrm{SiO}_{2}$-deposited PET samples. S. aureus and E. coli were purchased from the Korean Collection for Type Culture (KCTC, Daejeon, Korea) and American Type Culture Collection (ATCC, Manassas, VA, USA), respectively. Bacterial strains were preserved at $-80^{\circ} \mathrm{C}$ in LB broth, Miller (Difco Laboratories) containing 20\% v/v glycerol (Bioshop GLY001.1). Before preparing the suspension culture, bacteria were subcultured on LB agar (LB broth Miller and Bacto Agar; Difco Laboratories) at $37^{\circ} \mathrm{C}$ overnight. Single colonies from the streak plate were picked and inoculated into $5 \mathrm{~mL}$ LB broth in a round-bottom tube. The bacterial suspension was then incubated at $37^{\circ} \mathrm{C}$ overnight in a shaking incubator at $200 \mathrm{rpm}$.

\subsection{Assessment of Antibacterial Activity or Bacterial Adhesion}

Antibacterial activity against E. coli and S. aureus was assessed, as illustrated in Figure 3. Bacterial suspensions were diluted serially to reach an $\mathrm{OD}_{600}$ value of 0.1 , which is equivalent to a final concentration of $10^{8} \mathrm{CFU} / \mathrm{mL}$ (0.5 McFarland standard). One hundred 
microliters of each suspension were added and spread directly onto LB agar plates. The samples sized $1 \times 1 \mathrm{~cm}$ were placed on top of the agar surface and incubated for $12 \mathrm{~h}$ at $37^{\circ} \mathrm{C}$. Samples were detached from the plate and rinsed gently in 1X PBS to remove non-adherent cells. Detached samples were placed in fresh LB broth and vortexed for $1 \mathrm{~min}$. The liquid was transferred into a 48 -well plate $(500 \mu \mathrm{L}$ per well), and absorbance was measured using an Epoch microplate spectrophotometer (Bio-Tek Instruments, Winooski, VT, USA) at $600 \mathrm{~nm}$. The percentage of bacterial inhibition in the $\mathrm{SiO}_{2}$-deposited PET samples was calculated as follows:

$$
\text { Inhibition }(\%)=\left(1-\frac{\text { Average absorbance of silica deposited PET sample }}{\text { Average absorbance of plain PET sample }}\right) \times 100 \%
$$

\subsection{Live/Dead Assays for Bacteria}

Live/dead assays were performed using a LIVE/DEAD BacLight Bacterial viability kit (cat\# L7007, Thermo Scientific, Waltham, MA, USA) according to the manufacturer's protocol. This assay was only performed for visualizing S. aureus because we used GFPtagged E. coli. Samples were attached to the surface of the agar plate and detached after $12 \mathrm{~h}$ of incubation. Samples were then transferred to round-bottom tubes containing $1 \mathrm{~mL}$ LB broth and vortexed for $1 \mathrm{~min}$ to detach bacteria from the surface. The liquid was transferred into a $1.5 \mathrm{~mL}$ microcentrifuge tube and centrifuged at $10,000 \times \mathrm{g}$ for $15 \mathrm{~min}$. The staining solution was prepared by adding $3 \mu \mathrm{L}$ dye mixture from the kit with a 1:1 ratio of components A and B in $500 \mu \mathrm{L}$ LB broth. To visualize the presence of bacteria in the samples, $500 \mu \mathrm{L}$ supernatant was discarded from the tube, and $503 \mu \mathrm{L}$ of a previously prepared staining solution was added, followed by incubation for $15 \mathrm{~min}$ at room temperature in the dark. A $10 \mu \mathrm{L}$ drop of the stained suspension was trapped between the glass slide and cover slip. Fluorescence imaging was performed using an SZX16 stereo zoom microscope (Olympus, Tokyo, Japan).

\subsection{Cell Culture}

HDFs (Daewoong Pharmaceutical Company, Seoul, Korea) were seeded into 96- and 24-well tissue culture plates at $5 \times 10^{4}$ cells $/ \mathrm{cm}$, cultured in growth medium (DMEM (Corning, Oneonta, NY, USA) supplemented with 10\% FBS (Gibco-BRL, Gaithersburg, MD, USA) and $1 \% \mathrm{P} / \mathrm{S}(10,000 \mathrm{U} / \mathrm{mL}$ penicillin and 10,000 $\mathrm{g} / \mathrm{mL}$ streptomycin; Gibco-BRL)), and incubated at $37^{\circ} \mathrm{C}$ in a humidified incubator with $5 \% \mathrm{CO}_{2}$ for $24 \mathrm{~h}$. Cells were then subjected to cytotoxicity tests when they reached $100 \%$ confluence.

\subsection{In Vitro Cytotoxicity Tests and Cell Viability Analysis Using HDFs}

Cytotoxicity tests were performed using MTT assays (Invitrogen Corporation, Carlsbad, CA, USA) in 96-well plates, as described previously [59]. Conditioned medium was prepared by incubating cells in growth medium for $24 \mathrm{~h}$. The growth medium in 96-well plates was aspirated, and cells were washed with 1X PBS and incubated with conditioned medium for an additional $24 \mathrm{~h}$. MTT assays were then performed by mixing $10 \mu \mathrm{L}$ of $5 \mathrm{mg} / \mathrm{mL}$ MTT in $100 \mu \mathrm{L}$ growth medium in each well, followed by a $2 \mathrm{~h}$ incubation. MTT solution was aspirated and DMSO (Samchun Chemicals) was added to each well, followed by gentle resuspension. The plates were incubated for $10 \mathrm{~min}$, and the absorbance was measured using a microplate reader (Epoch Microplate Spectrophotometer; BioTek, Winooski, VT, USA) at $540 \mathrm{~nm}$. Cell viability was calculated using the following formula:

Viability $(\%)=\left(\frac{\text { Average absorbance of plain PET or silica deposited PET samples }}{\text { Average absorbance of cell in growth media }}\right) \times 100 \%$

To visualize cell morphology, cells were seeded at the same cell density as in MTT assays in 24-well tissue culture plates and cultured until they reached $100 \%$ confluence. The medium was then discarded and replaced with conditioned medium, and cells were incubated at $37^{\circ} \mathrm{C}$ for an additional $24 \mathrm{~h}$. For better visualization, cells were labeled with a 
fluorescence tracker (CellTracker Green CMFDA; Invitrogen Corporation). The staining dye was diluted in DMEM at a 1:1000 ratio and added to each well. Cells were then incubated at $37^{\circ} \mathrm{C}$ for $40 \mathrm{~min}$ and washed with $1 \mathrm{X}$ PBS. Imaging was performed using a fluorescence microscope (Eclipse Ti-U; Nikon, Tokyo, Japan) at the Soonchunhyang Biomedical Research Core Facility of KBSI.

\subsection{Statistical Analysis}

All values are shown as means \pm standard deviations of three replicates for each group, and statistical significance was assessed by one-way analysis of variance with Tukey's multiple comparison tests using GraphPad Prism software. Results with $p$ value less than 0.05 were considered significant $\left({ }^{*} p<0.05 ;{ }^{* *} p<0.01\right.$; ${ }^{* *} p<0.001$ of three replicates).

\section{Conclusions}

In this study, we investigated the antibacterial properties of $\mathrm{SiO}_{2}$-deposited hydrophobic surfaces of PET films, which were developed using a novel electrospray-based method. Unlike the conventional electrospray technique, our approach features a novelty in the application of AC voltage under the substrate holder instead of ground (zero) voltage to enhance the efficiency and uniformity of silica deposition. This strategy successfully created a hydrophobic surface with antibacterial features against both Gram-positive and Gramnegative bacteria. The $\mathrm{SiO}_{2}$-deposited surface was characterized by SEM, FTIR, WCA, and AFM analyses. The hydrophobicity of the $\mathrm{SiO}_{2}$-deposited surface was confirmed (WCA value $118.1^{\circ} \pm 7.2^{\circ}, R_{R M S}$ value of $82.50 \pm 16.22 \mathrm{~nm}$, and $R_{a}$ value of $65.15 \pm 15.26 \mathrm{~nm}$ ), and the inhibition rates against E. coli and S. aureus were $66 \%$ and $64 \%$, respectively. Furthermore, these results were consistent with the fluorescence images, which showed a low adherence of bacteria on the $\mathrm{SiO}_{2}$-deposited surface. We also performed cytotoxicity tests for in vitro cell culture and demonstrated greater than $90 \%$ viability in HDFs, suggesting that the $\mathrm{SiO}_{2}$-deposited surface had good biocompatibility. Therefore, our findings demonstrated that a novel electrospray based $\mathrm{SiO}_{2}$ deposition on to PET films could exhibit highly antibacterial and biocompatible properties and our fabricated hydrophobic surfaces may be suitable for use in various biomedical applications.

Supplementary Materials: The following are available online at https:/ /www.mdpi.com/article/10 $.3390 /$ ijms23010513/s1.

Author Contributions: Conceptualization and methodology: O.L., S.H., K.-S.K., and Y.H.; investigation, formal analysis: O.L., S.H., S.H.K., J.H.J., S.S.H., J.W.L., K.-S.K., and Y.H.; writing-original draft preparation and writing-review and editing: O.L., S.H., S.H.K., J.H.J., K.-S.K., and Y.H.; funding acquisition: S.H. and Y.H. All authors have read and agreed to the published version of the manuscript.

Funding: This research was partially supported by the Soonchunhyang University Research Fund and supported by the Brain Pool Program through the National Research Foundation of Korea (NRF) funded by the Ministry of Science and ICT (grant no. 2019H1D3A2A02102074).

Institutional Review Board Statement: Not applicable.

Informed Consent Statement: Not applicable.

Data Availability Statement: The data presented in this study are available upon request from the corresponding authors.

Acknowledgments: This research was supported by the Naval Institute for Ocean Research of the Republic of Korea Naval Academy.

Conflicts of Interest: The authors declare no conflict of interest. The funders had no role in the study design; in the collection, analyses, or interpretation of data; in the writing of the manuscript; or in the decision to publish the results. 


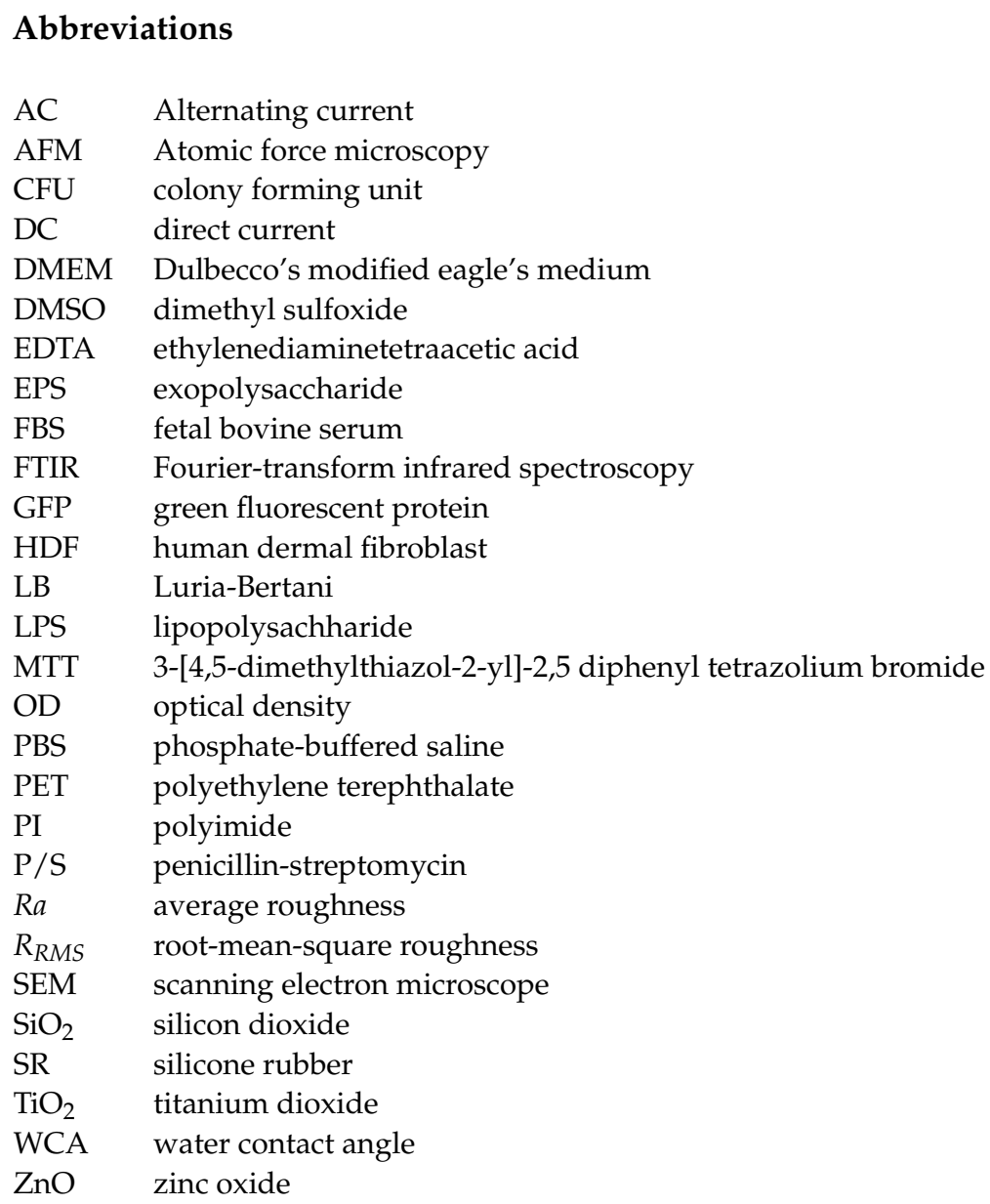

\section{References}

1. Hall-Stoodley, L.; Costerton, J.W.; Stoodley, P. Bacterial biofilms: From the natural environment to infectious diseases. Nat. Rev. Microbiol. 2004, 2, 95-108. [CrossRef]

2. Kaplan, J.B. Biofilm dispersal: Mechanisms, clinical implications, and potential therapeutic uses. J. Dent. Res 2010, 89, 205-218. [CrossRef] [PubMed]

3. Kostakioti, M.; Hadjifrangiskou, M.; Hultgren, S.J. Bacterial biofilms: Development, dispersal, and therapeutic strategies in the dawn of the postantibiotic era. Cold Spring Harb. Perspect. Med. 2013, 3, a010306. [CrossRef]

4. Dertli, E.; Mayer, M.J.; Narbad, A. Impact of the exopolysaccharide layer on biofilms, adhesion and resistance to stress in Lactobacillus johnsonii FI9785. BMC Microbiol. 2015, 15, 1-9. [CrossRef] [PubMed]

5. Bjarnsholt, T. The role of bacterial biofilms in chronic infections. APMIS 2013, 121, 1-58. [CrossRef]

6. Taraszkiewicz, A.; Fila, G.; Grinholc, M.; Nakonieczna, J. Innovative strategies to overcome biofilm resistance. Biomed. Res. Int. 2013, 2013, 150653. [CrossRef] [PubMed]

7. Wei, T.; Zhan, W.; Cao, L.; Hu, C.; Qu, Y.; Yu, Q.; Chen, H. Multifunctional and Regenerable Antibacterial Surfaces Fabricated by a Universal Strategy. ACS Appl. Mater. Interfaces 2016, 8, 30048-30057. [CrossRef]

8. Jung, S.W.; Oh, S.H.; Lee, I.S.; Byun, J.H.; Lee, J.H. In Situ Gelling Hydrogel with Anti-Bacterial Activity and Bone Healing Property for Treatment of Osteomyelitis. Tissue Eng. Regen. Med. 2019, 16, 479-490. [CrossRef]

9. Klemm, P.; Vejborg, R.M.; Hancock, V. Prevention of bacterial adhesion. Appl. Microbiol. Biotechnol. 2010, 88, 451-459. [CrossRef]

10. Ga, D.H.; Lim, C.M.; Jang, Y.; Son, T.I.; Han, D.K.; Joung, Y.K. Surface-Modifying Effect of Zwitterionic Polyurethane Oligomers Complexed with Metal Ions on Blood Compatibility. Tissue Eng. Regen. Med. 2021. [CrossRef] [PubMed]

11. Asadi, A.; Razavi, S.; Talebi, M.; Gholami, M. A review on anti-adhesion therapies of bacterial diseases. Infection 2019, 47, 13-23. [CrossRef]

12. Falde, E.J.; Yohe, S.T.; Colson, Y.L.; Grinstaff, M.W. Superhydrophobic materials for biomedical applications. Biomaterials 2016, 104, 87-103. [CrossRef]

13. Elzaabalawy, A.; Verberne, P.; Meguid, S.A. Multifunctional Silica-Silicone Nanocomposite with Regenerative Superhydrophobic Capabilities. ACS Appl. Mater. Interfaces 2019, 11, 42827-42837. [CrossRef]

14. Yuan, Y.; Hays, M.P.; Hardwidge, P.R.; Kim, J. Surface characteristics influencing bacterial adhesion to polymeric substrates. RSC Adv. 2017, 7, 14254-14261. [CrossRef] 
15. Hemmatian, T.; Lee, H.; Kim, J. Bacteria Adhesion of Textiles Influenced by Wettability and Pore Characteristics of Fibrous Substrates. Polymers 2021, 13, 223. [CrossRef]

16. Jalvo, B.; Faraldos, M.; Bahamonde, A.; Rosal, R. Antibacterial surfaces prepared by electrospray coating of photocatalytic nanoparticles. Chem. Eng. J. 2018, 334, 1108-1118. [CrossRef]

17. Yoon, H.; Joshi, B.; Na, S.H.; Yoon, S.S. Antibacterial Activity and Photocatalysis of Electrosprayed Titania Films. J. Electrochem. Soc. 2012, 159, H823-H827. [CrossRef]

18. Zare, M.; Ghomi, E.R.; Venkatraman, P.D.; Ramakrishna, S. Silicone-based biomaterials for biomedical applications: Antimicrobial strategies and 3D printing technologies. J. Appl. Polym. Sci. 2021, 138, 50969. [CrossRef]

19. Wang, J.; Wu, G.F.; Liu, X.W.; Sun, G.Y.; Li, D.H.; Wei, H.B. A decomposable silica-based antibacterial coating for percutaneous titanium implant. Int. J. Nanomed. 2017, 12, 371-379. [CrossRef]

20. Vladkova, T.; Angelov, O.; Stoyanova, D.; Gospodinova, D.; Gomes, L.; Soares, A.; Mergulhao, F.; Ivanova, I. Magnetron co-sputtered $\mathrm{TiO} 2 / \mathrm{SiO} 2 / \mathrm{Ag}$ nanocomposite thin coatings inhibiting bacterial adhesion and biofilm formation. Surf. Coat. Technol. 2020, 384. [CrossRef]

21. Swar, S.; Zajicova, V.; Rysova, M.; Lovetinska-Slamborova, I.; Volesky, L.; Stibor, I. Biocompatible surface modification of poly(ethylene terephthalate) focused on pathogenic bacteria: Promising prospects in biomedical applications. J. Appl. Polym. Sci. 2017, 134. [CrossRef]

22. Caykara, T.; Sande, M.G.; Azoia, N.; Rodrigues, L.R.; Silva, C.J. Exploring the potential of polyethylene terephthalate in the design of antibacterial surfaces. Med. Microbiol. Immunol. 2020, 209, 363-372. [CrossRef]

23. Rahman, M.K.; Phung, T.H.; Oh, S.; Kim, S.H.; Ng, T.N.; Kwon, K.S. High-Efficiency Electrospray Deposition Method for Nonconductive Substrates: Applications of Superhydrophobic Coatings. ACS Appl. Mater. Interfaces 2021, 13, 18227-18236. [CrossRef]

24. Zhi, D.F.; Wang, H.H.; Jiang, D.; Parkin, I.P.; Zhang, X. Reactive silica nanoparticles turn epoxy coating from hydrophilic to super-robust superhydrophobic. RSC Adv. 2019, 9, 12547-12554. [CrossRef]

25. Feifel, S.C.; Lisdat, F. Silica nanoparticles for the layer-by-layer assembly of fully electro-active cytochrome c multilayers. $J$. Nanobiotechnology 2011, 9, 59. [CrossRef] [PubMed]

26. Habila, M.A.; ALOthman, Z.A.; El-Toni, A.M.; Labis, J.P.; Soylak, M. Synthesis and application of Fe3O4@SiO2@TiO2 for photocatalytic decomposition of organic matrix simultaneously with magnetic solid phase extraction of heavy metals prior to ICP-MS analysis. Talanta 2016, 154, 539-547. [CrossRef] [PubMed]

27. Handke, M.; Sitarz, M.; Dlugon, E. Amorphous SiCxOy coatings from ladder-like polysilsesquioxanes. J. Mol. Struct. 2011, 993, 193-197. [CrossRef]

28. Nunes, C.S.; da Silva, M.J.V.; da Silva, D.C.; Freitas, A.R.; Rosa, F.A.; Rubira, A.F.; Muniz, E.C. PET depolymerisation in supercritical ethanol catalysed by [Bmim][BF4]. RSC Adv. 2014, 4, 20308-20316. [CrossRef]

29. Paszkiewicz, S.; Szymczyk, A.; Pawlikowska, D.; Irska, I.; Taraghi, I.; Pilawka, R.; Gu, J.L.; Li, X.H.; Tu, Y.F.; Piesowicz, E. Synthesis and characterization of poly(ethylene terephthalate-co-1,4-cyclohexanedimethylene terephtlatate)-block-poly(tetramethylene oxide) copolymers. RSC Adv. 2017, 7, 41745-41754. [CrossRef]

30. Chen, Z.Y.; Hay, J.N.; Jenkins, M.J. FTIR spectroscopic analysis of poly(ethylene terephthalate) on crystallization. Eur. Polym. J. 2012, 48, 1586-1610. [CrossRef]

31. Zheng, S.; Bawazir, M.; Dhall, A.; Kim, H.E.; He, L.; Heo, J.; Hwang, G. Implication of Surface Properties, Bacterial Motility, and Hydrodynamic Conditions on Bacterial Surface Sensing and Their Initial Adhesion. Front. Bioeng. Biotech. 2021, 9, 643722. [CrossRef]

32. Startek, K.; Szczurek, A.; Tran, T.N.L.; Krzak, J.; Bachmatiuk, A.; Lukowiak, A. Structural and Functional Properties of Fluorinated Silica Hybrid Barrier Layers on Flexible Polymeric Foil. Coatings 2021, 11, 573. [CrossRef]

33. Ozkan, E.; Crick, C.C.; Taylor, A.; Allan, E.; Parkin, I.P. Copper-based water repellent and antibacterial coatings by aerosol assisted chemical vapour deposition. Chem. Sci. 2016, 7, 5126-5131. [CrossRef] [PubMed]

34. Svirinovsky, A.; Perelshtein, I.; Natan, M.; Banin, E.; Gedanken, A. Imparting superhydrophobic and biocidal functionalities to a polymeric substrate by the sonochemical method. Ultrason. Sonochem. 2018, 44, 398-403. [CrossRef]

35. Park, K.; Jeong, H.; Tanum, J.; Yoo, J.C.; Hong, J. Developing regulatory property of gelatin-tannic acid multilayer films for coating-based nitric oxide gas delivery system. Sci. Rep. 2019, 9, 8308. [CrossRef]

36. Grice, E.A.; Segre, J.A. The skin microbiome. Nat. Rev. Microbiol. 2011, 9, 244-253. [CrossRef]

37. Poojari, Y. Silicones for Encapsulation of Medical Device Implants. Silicon-Neth. 2017, 9, 645-649. [CrossRef]

38. Shah, K.W. Nanosynthesis Techniques of Silica-Coated Nanostructures. In Novel Nanomaterials-Synthesis and Applications; Kyzas, G.Z., Mitropoulos, A.C., Eds.; IntechOpen: London, UK, 2018.

39. Lei, L.; Gamboa, A.R.; Kuznetsova, C.; Littlecreek, S.; Wang, J.; Zou, Q.; Zahn, J.D.; Singer, J.P. Self-limiting electrospray deposition on polymer templates. Sci. Rep. 2020, 10, 17290. [CrossRef]

40. Tang, J.; Gomez, A. Controlled mesoporous film formation from the deposition of electrosprayed nanoparticles. Aerosol. Sci. Tech. 2017, 51, 755-765. [CrossRef]

41. Parhizkar, M.; Reardon, P.J.T.; Knowles, J.C.; Browning, R.J.; Stride, E.; Pedley, R.B.; Grego, T.; Edirisinghe, M. Performance of novel high throughput multi electrospray systems for forming of polymeric micro/nanoparticles. Mater. Des. 2017, 126, 73-84. [CrossRef] 
42. Nishimoto, S.; Bhushan, B. Bioinspired self-cleaning surfaces with superhydrophobicity, superoleophobicity, and superhydrophilicity. RSC Adv. 2013, 3, 671-690. [CrossRef]

43. Parvate, S.; Dixit, P.; Chattopadhyay, S. Superhydrophobic Surfaces: Insights from Theory and Experiment. J. Phys. Chem. B 2020, 124, 1323-1360. [CrossRef]

44. Privett, B.J.; Youn, J.; Hong, S.A.; Lee, J.; Han, J.; Shin, J.H.; Schoenfisch, M.H. Antibacterial Fluorinated Silica Colloid Superhydrophobic Surfaces. Langmuir 2011, 27, 9597-9601. [CrossRef] [PubMed]

45. Protsak, I.S.; Morozov, Y.M.; Zhang, D.; Gun'ko, V.M. Surface Chemistry of Nanohybrids with Fumed Silica Functionalized by Polydimethylsiloxane/Dimethyl Carbonate Studied Using (1)H, (13)C, and (29)Si Solid-State NMR Spectroscopy. Molecules 2021, 26, 5974. [CrossRef]

46. Koubali, H.; El Louali, M.; Zahir, H.; Soufiani, S.; Mabrouki, M.; Latrache, H. Physicochemical characterization of glass and polyethylene surfaces treated with different surfactants and their effects on bacterial adhesion. Int. J. Adhes. Adhes. 2021, 104, 102754. [CrossRef]

47. Li, A.L.; Wang, G.F.; Ma, Y.W.; Zhao, C.Y.; Zhang, F.Y.; He, Q.; Zhang, F.W. Study on preparation and properties of superhydrophobic surface of RTV silicone rubber. J. Mater. Res. Technol. 2021, 11, 135-143. [CrossRef]

48. Schneider, L.; Laustsen, M.; Mandsberg, N.; Taboryski, R. The Influence of Structure Heights and Opening Angles of Micro- and Nanocones on the Macroscopic Surface Wetting Properties. Sci. Rep. 2016, 6, 21400. [CrossRef] [PubMed]

49. Guzel Kaya, G.; Medaglia, S.; Candela-Noguera, V.; Tormo-Mas, M.A.; Marcos, M.D.; Aznar, E.; Deveci, H.; Martinez-Manez, R. Antibacterial Activity of Linezolid against Gram-Negative Bacteria: Utilization of epsilon-Poly-l-Lysine Capped Silica Xerogel as an Activating Carrier. Pharmaceutics 2020, 12, 1126. [CrossRef]

50. Hasan, J.; Jain, S.; Padmarajan, R.; Purighalla, S.; Sambandamurthy, V.K.; Chatterjee, K. Multi-scale surface topography to minimize adherence and viability of nosocomial drug-resistant bacteria. Mater. Des. 2018, 140, 332-344. [CrossRef]

51. Zhang, X.X.; Wang, L.; Levanen, E. Superhydrophobic surfaces for the reduction of bacterial adhesion. RSC Adv. 2013, 3, 12003-12020. [CrossRef]

52. Duvernoy, M.C.; Mora, T.; Ardre, M.; Croquette, V.; Bensimon, D.; Quilliet, C.; Ghigo, J.M.; Balland, M.; Beloin, C.; Lecuyer, S.; et al. Asymmetric adhesion of rod-shaped bacteria controls microcolony morphogenesis. Nat. Commun. 2018, 9, 1120. [CrossRef]

53. Dorr, T.; Moynihan, P.J.; Mayer, C. Editorial: Bacterial Cell Wall Structure and Dynamics. Front. Microbiol. $2019,10,2051$. [CrossRef] [PubMed]

54. Beaussart, A.; El-Kirat-Chatel, S. Microbial adhesion and ultrastructure from the single-molecule to the single-cell levels by Atomic Force Microscopy. Cell Surf. 2019, 5, 100031. [CrossRef]

55. Lima, M.; Teixeira-Santos, R.; Gomes, L.C.; Faria, S.I.; Valcarcel, J.; Vazquez, J.A.; Cerqueira, M.A.; Pastrana, L.; Bourbon, A.I.; Mergulhao, F.J. Development of Chitosan-Based Surfaces to Prevent Single- and Dual-Species Biofilms of Staphylococcus aureus and Pseudomonas aeruginosa. Molecules 2021, 26, 4378. [CrossRef] [PubMed]

56. Di Ciccio, P.; Vergara, A.; Festino, A.R.; Paludi, D.; Zanardi, E.; Ghidini, S.; Ianieri, A. Biofilm formation by Staphylococcus aureus on food contact surfaces: Relationship with temperature and cell surface hydrophobicity. Food Control 2015, 50, 930-936. [CrossRef]

57. Niemirowicz, K.; Surel, U.; Wilczewska, A.Z.; Mystkowska, J.; Piktel, E.; Gu, X.; Namiot, Z.; Akowska, A.K.L.; Savage, P.B.; Bucki, R. Bactericidal activity and biocompatibility of ceragenin-coated magnetic nanoparticles. J. Nanobiotechnol. 2015, 13, 32. [CrossRef] [PubMed]

58. Nakade, K.; Jindai, K.; Sagawa, T.; Kojima, H.; Shimizu, T.; Shingubara, S.; Ito, T. Adhesion and Bactericidal Properties of a Wettability-Controlled Artificial Nanostructure. ACS Appl. Nano. Mater. 2018, 1, 5736-5741. [CrossRef]

59. Pillai, S.K.R.; Reghu, S.; Vikhe, Y.; Zheng, H.; Koh, C.H.; Chan-Park, M.B. Novel Antimicrobial Coating on Silicone Contact Lens Using Glycidyl Methacrylate and Polyethyleneimine Based Polymers. Macromol. Rapid Comm. 2020, 41, 2000175. [CrossRef] [PubMed]

60. Dulski, M.; Gawecki, R.; Sulowicz, S.; Cichomski, M.; Kazek-Kesik, A.; Wala, M.; Lesniak-Ziolkowska, K.; Simka, W.; MrozekWilczkiewicz, A.; Gaweda, M.; et al. Key Properties of a Bioactive Ag-SiO2/TiO2 Coating on NiTi Shape Memory Alloy as Necessary at the Development of a New Class of Biomedical Materials. Int. J. Mol. Sci. 2021, 22, 507. [CrossRef]

61. Chi, F.; Zeng, Y.; Liu, C.; Liang, D.; Li, Y.; Xie, R.; Pan, N.; Ding, C. Enhancing mechanical stability of sol-gel silica antireflection coatings via ammonia treatment at low temperature. Results Phys. 2020, 18, 103315. [CrossRef]

62. Navarro-Palomares, E.; Gonzalez-Saiz, P.; Renero-Lecuna, C.; Martin-Rodriguez, R.; Aguado, F.; Gonzalez-Alonso, D.; Barquin, L.; Gonzalez, J.; Banobre-Lopez, M.; Fanarraga, M.L.; et al. Dye-doped biodegradable nanoparticle SiO2 coating on zinc- and iron-oxide nanoparticles to improve biocompatibility and for in vivo imaging studies. Nanoscale 2020, 12, 6164-6175. [CrossRef] [PubMed]

63. Fritsch-Decker, S.; An, Z.; Yan, J.; Hansjosten, I.; Al-Rawi, M.; Peravali, R.; Diabate, S.; Weiss, C. Silica Nanoparticles Provoke Cell Death Independent of p53 and BAX in Human Colon Cancer Cells. Nanomaterials 2019, 9, 1172. [CrossRef] [PubMed]

64. Remzova, M.; Zouzelka, R.; Brzicova, T.; Vrbova, K.; Pinkas, D.; Rossner, P.; Topinka, J.; Rathousky, J. Toxicity of TiO2, ZnO, and $\mathrm{SiO} 2$ Nanoparticles in Human Lung Cells: Safe-by-Design Development of Construction Materials. Nanomaterials $2019,9,968$. [CrossRef] [PubMed]

65. Yilbas, B.S.; Al-Sharafi, A.; Ali, H.; Al-Aqeeli, N. Dynamics of a water droplet on a hydrophobic inclined surface: Influence of droplet size and surface inclination angle on droplet rolling. RSC Adv. 2017, 7, 48806-48818. [CrossRef] 